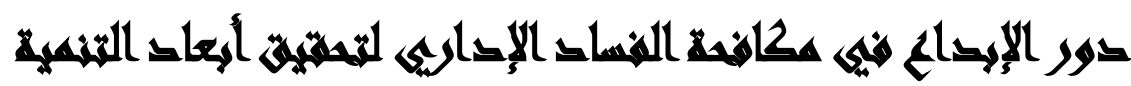

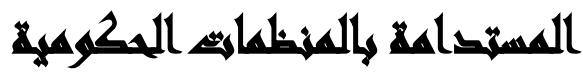

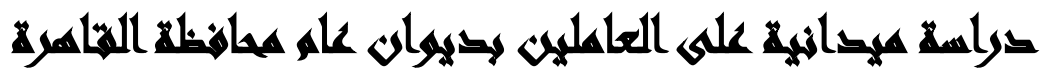

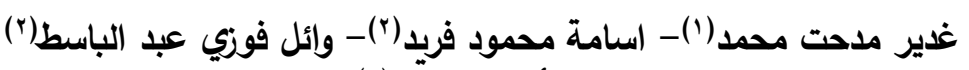

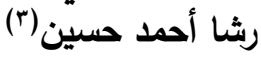

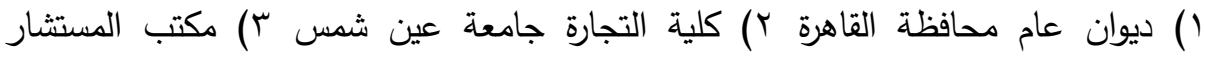
القانوني بمحافظة القاهرة

\section{varing}

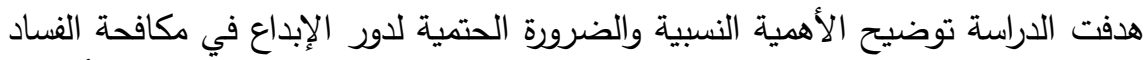

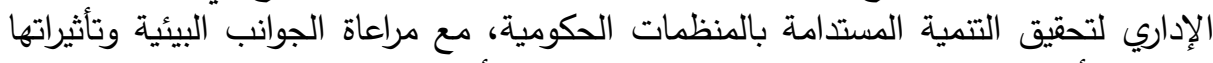

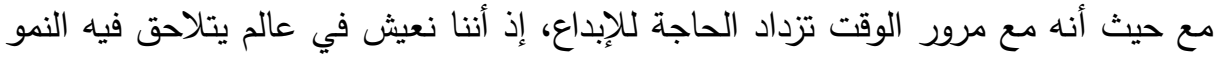

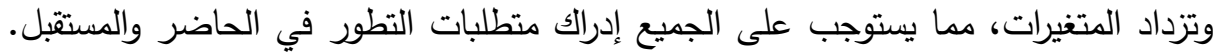

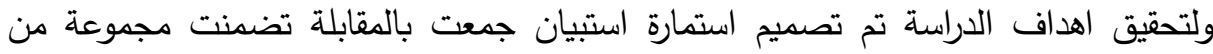

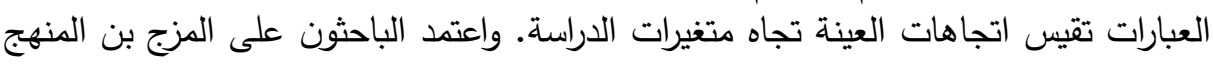

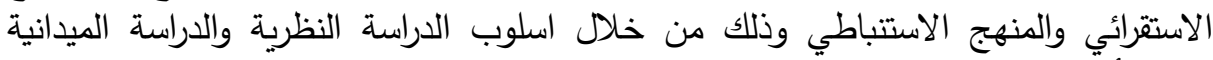

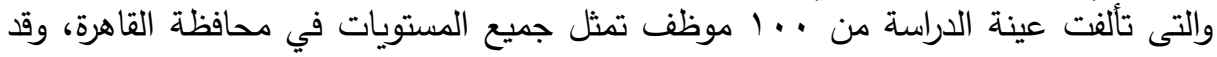
قام الباحثون بإجراء تحليل البيانات باستخدام طريقة الاختبار وإعادة الآختبار (test-re-test)

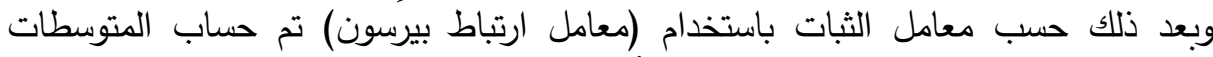

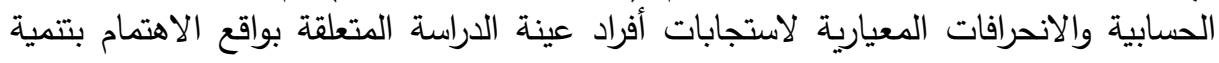
الإبداع في الادارات المستقلة.

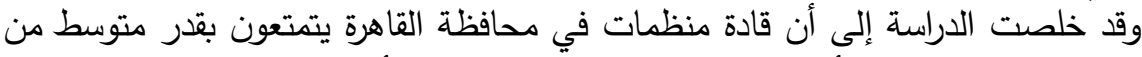

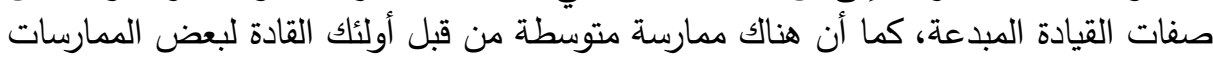

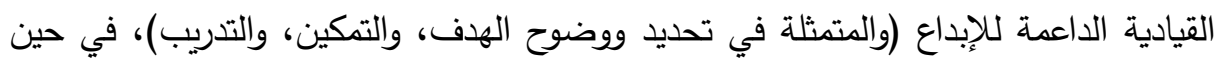

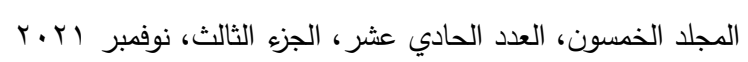

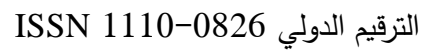

$$
\begin{aligned}
& \text { الترقيم الدولي الموحد الإكتروني 3178-2636-26 }
\end{aligned}
$$


كانت هنالك ممارسة ضعيفة لكل من الحوافز والمكافآت، وقد أشارت النتائج إلى عملية فتح

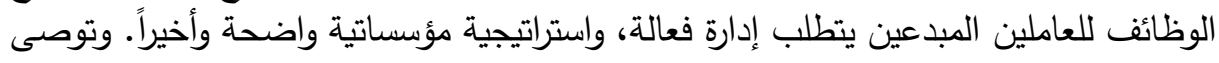

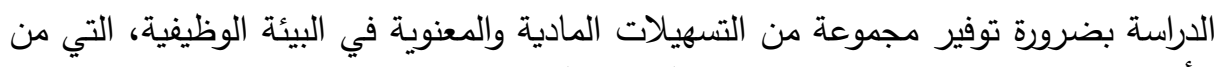

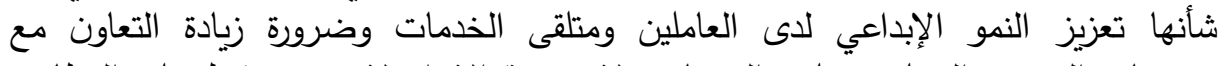

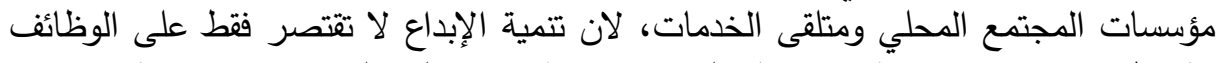

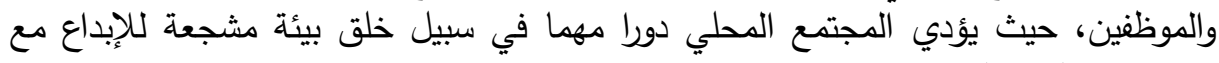
تدريب العاملين على استخدام الاستراتيجيات التي تتمي الابتكار .

\section{Xavall}

أصبحت البيئة أحد الاتجاهات المهمة التي حظيت باهتمام كبير في السنوات الأخيرة في

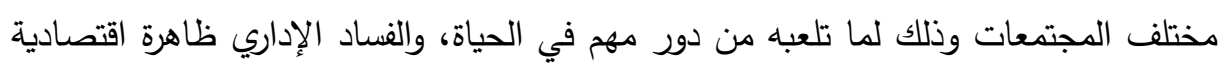

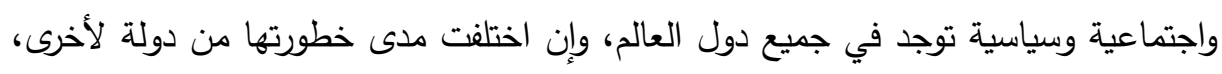

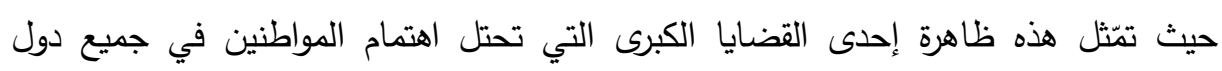

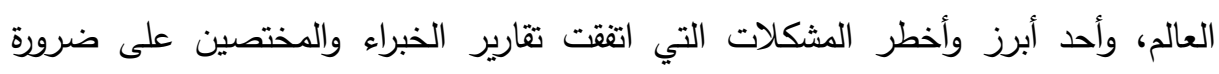
مكافحتها وعلاجها، وذلك لما لها من قدرة على انتهاك للقيم والمعايير الأخلاقية من جهة،

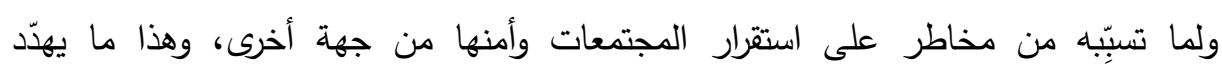

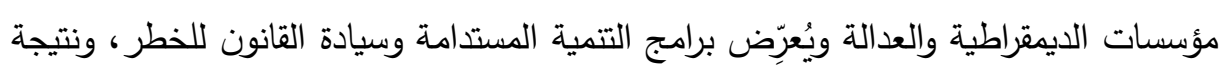
لهذه الآثار السلبية وغيرها فقد أصبحت ظاهرة الفساد الإداري واحدة من المواضيع الرئيسية

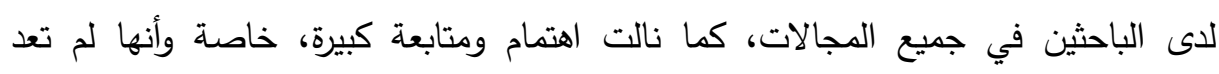
مقتصرة على دولة من الدول وإنما ظاهرة عالمية لا حدود لها، مما جعلها تتصدر أهم القضايا الكبرى في العالم إذ فرضت نفسها على أجندة الصحف والجمهور، وأصبحت تحظى باهتمام

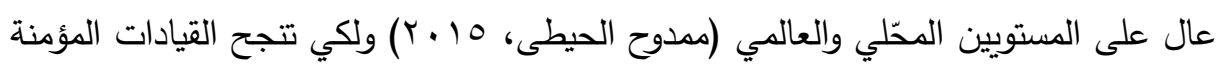

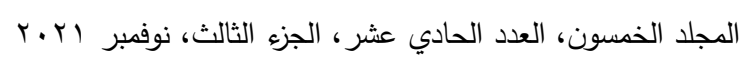

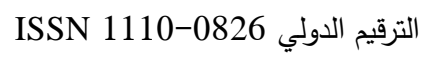

$$
\begin{aligned}
& \text { الترقيم الدولي الموحد الإكتروني 3178-2636 }
\end{aligned}
$$


بالإبداع في دفع الطاقات الإبداعية لدى العاملين نحو الإبداع، فلا بد من توفير المناخ التتظيمي والثقافة التتظيمية الملائمة لذلك، بخلق مناخ من الثقة المتبادلة بين القيادة

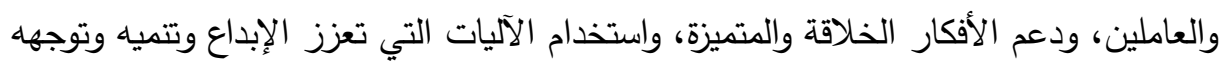

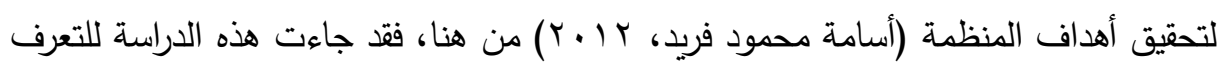
على أبرز وأهم الأدوار التي يلعبها الابداع لاعم، وتتمية مكافحة الفساد لاى العاملين في ديوان عام محافظة القاهرة بالمشاركة والرشد في اتخاذ القرارات بالتالي ضمانيان الابداعة استدامة بيئية واقتصادية واجتماعية وثقافية وتكنولوجية.

\section{Anangan}

رغم التحديث والتطوير الذي تقوم به محافظة القاهرة وإعادة هيكلة ديوان عام المحافظة والاستعانة بالخبراء والمستثارين من خارج المحافظة ورغم تثجيع محافظة القاهرة للعاملين على تقديم الاقتراحات والأفكار الجديدة وتتفيذ المفيد منها مما ساعد محافظة القاهرة كثيرًا في التقدم والتطوير الملحوظ ورغم التغيير في معظم أنثطة الموارد البشرية في محافظة القاهرة من

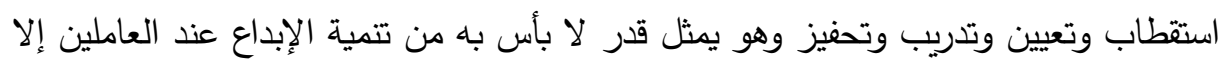

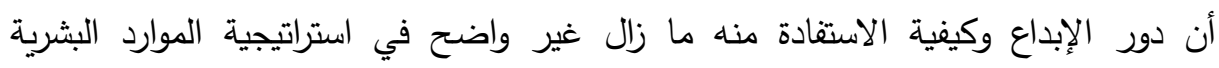
الموضوعة بمحافظة القاهرة. هذا وقد تم بلورة مشكلة البحث في النقاط الآتية: • مجموعة الدراسات السابقة العربية والأجنبية التي سيتم عرضها لاتيها لاحقا تبين القصور

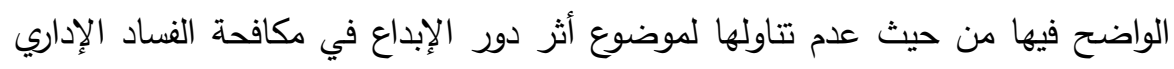
لتحقيق أبعاد التتمية المستدامة بالمنظمات الحكومية.

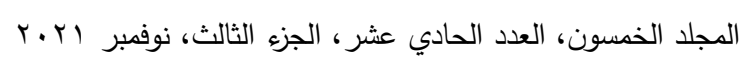

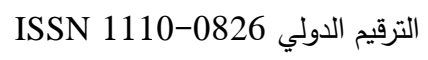

$$
\begin{aligned}
& \text { الترقيم الدولي الموحد الإكتروني 3178-2636 }
\end{aligned}
$$


الدراسة الاستطلاعية التي قام بها الباحثون وذلك للوقوف على جميع جوانب المشكلة

$$
\text { وتحديد جميع أركانها الأساسية من خلال الآتي: }
$$

- المقابلات الثخصية مع عدد ستة عشر من الإدارة العليا بديوان عام محافظة القاهرة محل الثل

- بعض المؤشرات غير المالية البسيطة التي حصل عليها الباحثون وكذا المؤشرات الخاصة بالتتمية المستدامة ومنها (نسبة العاملين الذين يحصلون على الخدمات الاساسية- نسبة اجمالي الانفاق الحكومي بالمحافظة على الخدمات الاجتماعية للعاملين- عدد العاملين

$$
\text { المتوفين والمصابين ومن تضرروا مباشرة بسبب العمل). }
$$

تكمن مشكلة البحث في محاولة دراسة ظاهرة الفساد الإداري والتي تعد من أخطر الآفات

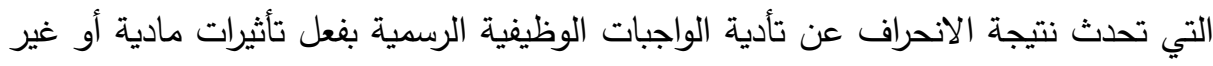

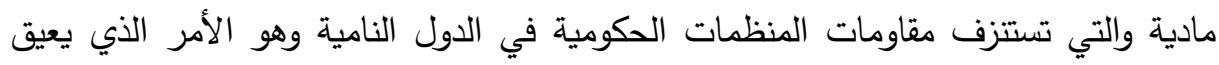
تحقيق التتمية المستدامة بهذه الدول، ويمكن صياغة مشكلة الدراسة في التساؤل الرئيسي التالي: ما هو دور الإبداع في مكافحة الفساد الإداري لتحقيق أبعاد التتمية المستدامة

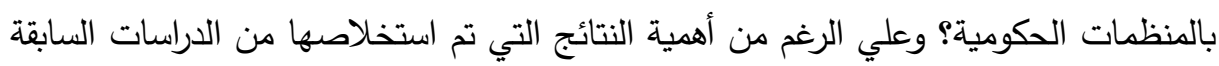

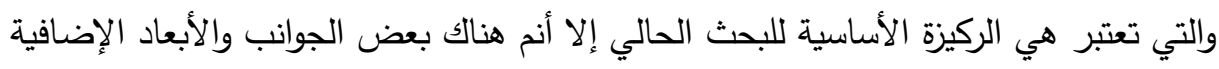

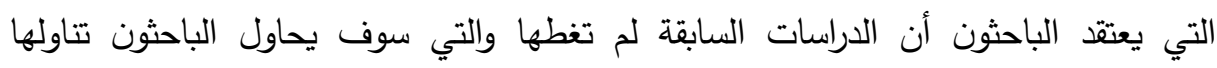
بالدراسة والتحليل والاختبار الميداني ومن أهم الجوانب ما يلي: اختبار العلاقة ميدانيا بين الابداع مكافحة الفساد الإداري و أبعاد التتمية المستدامة بالمنظمات الحكومية.

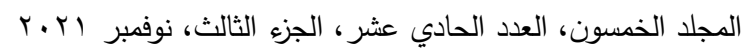

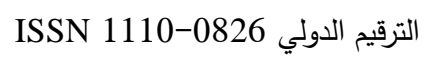

$$
\begin{aligned}
& \text { الترقيم الدولي الموحد الإكتروني 3178-2636 }
\end{aligned}
$$




$$
\begin{aligned}
& \text { مجلة العلوم البيئية } \\
& \text { كلية الدراسات العليا والبحوث البيئية - جامعة عين شمس لئية } \\
& \text { غدير مدحت محمد وآخرون }
\end{aligned}
$$

\section{السئلا المهيث}

التساؤل الرئيسي: ما هو دور الإبداع في مكافحة الفساد الإداري لتحقيق أبعاد التتمية المستدامة بالمنظمات الحكومية؟ لرئئ ويتفرع من هذا السؤال أسئلة فرعية أخرى: - ما مدى وجود ارتباط بين ابعاد التتمية المستدامة التي تضعها محافظة القاهرة وتتمية

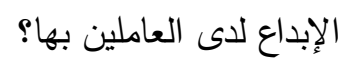
- ما مدى وجود ارتباط بين إعادة هيكلة العمل بطريقة مستمرة (توصيف الوظائف) وبين تتمية الإبداع لدى العاملين؟ مدا؟ - ما مدى وجود ارتباط بين اختيار العاملين وتتمية الإبداع لديهج؟

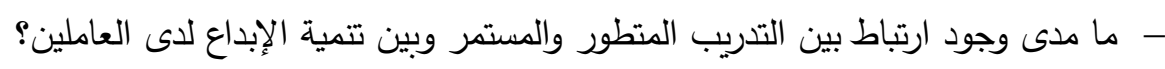
- ما مدى وجود ارتباط بين مكافحة الفناد وتنمية الإبداع لدى العاملين؟

\section{أهمية الهمبث}

الاهمية النظرية: الإشارة إلي دور الإبداع وأهيته في مكافحة الفساد الإداري للمساهمة في تحقيق أبعاد التتمية المستدامة، وذلك بداية من التعرف على ماهية وأهمية الإبداع، ومروراً

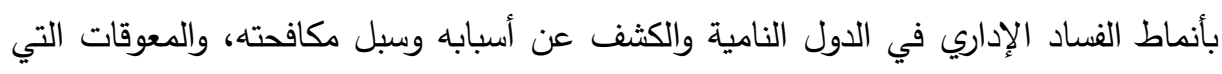
تواجه جهود مكافحته، وصولاً إلي مكافحة الفساد الإداري والمساهمة في تحقيق أبعاد التتمية المستدامة.

وتوصل المؤتمر الرابع عشر للمجلس العالمي للأطفال الموهوبين والمتفوقين في برشلونة

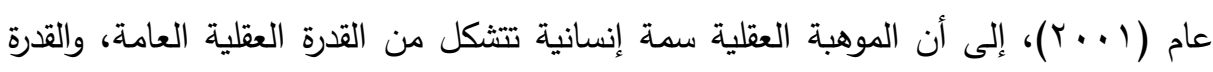

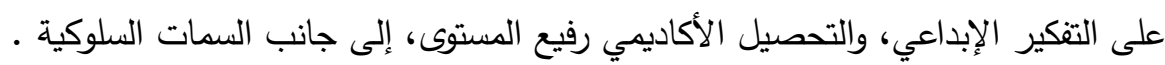

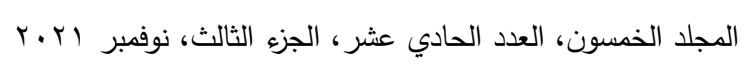

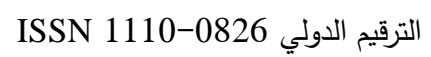

$$
\begin{aligned}
& \text { الترقيم الدولي الموحد الإكتروني 3178-2636 }
\end{aligned}
$$


ويعرف المجلس القومي للتعليم والبحث العلمي والتكنولوجيا الموهوب بأنه: الثخص الذي يتعلم بقدرة وسرعة تفوق بقية الأطفال المساوين له في العمر الزمني، ويعبر عن هذه القدرة

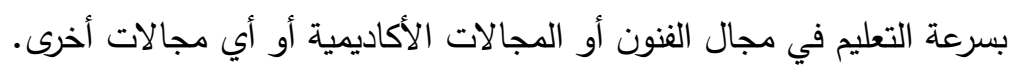

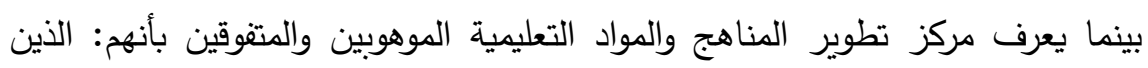
يحققون ما بين · با ا-. ـ ا درجة فأكثر في اختبارات الذكاء.

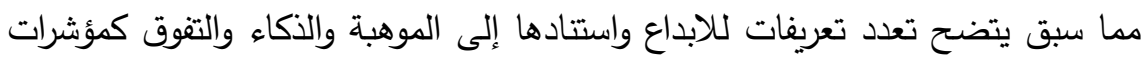

دالة عليها؛ مما يجعلها مفاهيم مصاحبة للموهبة جديرة بالعرض والإثارة إليها.

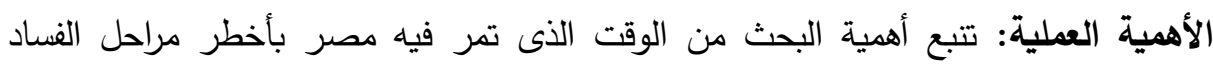

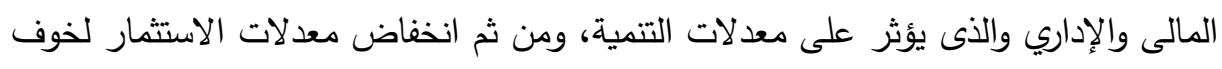

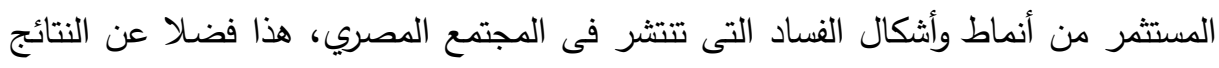
السلبية التى تؤثر على قيم وأخلاقيات المواطنين وانعكاسها على انخفاض مستوى المعيثة، ومن ثم على معدلات الإنتاج التى تكاد تتعدم لانتشار ثقافة الرشوة والفساد والمحسوبية.

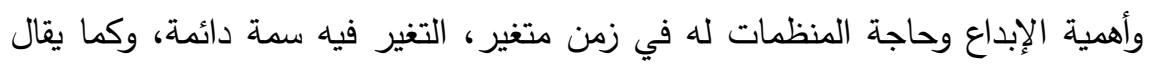
فإن الثابت الوحيد هو التغيير وحالة عدم الاستقرار، فلا أحد يمكنه التقليل من أهمية الإبداع والتجديد لمواجهة تحديات البيئة المتغيرة. تتمثل أهمية البحث على المستوى التطبيقي في النقاط الآتية:

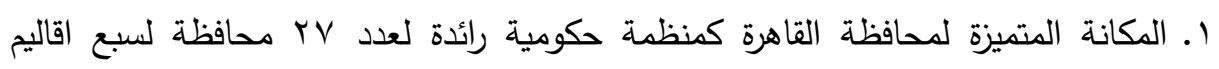
بجمهورية مصر العربية كهيئة خدمية تستحوذ على جزء كبير من في مجال تقديم

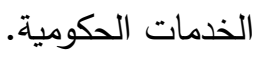

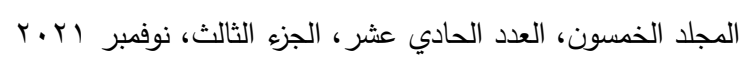

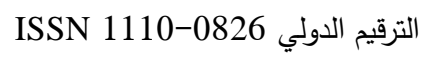

$$
\begin{aligned}
& \text { الترقيم الدولي الموحد الإكتروني 3178-2636 }
\end{aligned}
$$


r. محافظة القاهرة تخدم قطاع كبير من العملاء من جميع المستويات والأعمار بتقديم مجموعة كبيرة من الخدمات المتتوعة كما انها تمتلك ثروة بشريـة هائلة يمكن الاستفادة من تتوعها وطاقاتها وإبداعاتها في تطوير الخدمة المقدمة. r. موضوع الإبداع موضوع جديد ومهم خاصة في استراتيجيات مكافحة الفساد في المنظمات الحكومية.

\section{أهماهن المهيث}

يهدف البحث إلى دراسة وتوضيح الأهمية النسبية والضرورة الحتمية لدور الإبداع في مكافحة الفساد الإداري لتحقيق التتمية المستدامة بالمنظمات الحكومية التي تذكي جذوة الإبداع لدى العاملين في هذا القطاع الحكومى (ديوان محافظة القاهرة)، مع مراعاة الجوانب البيئية وتأثيراتها ويمكن تقسيم هذا الهدف العام إلى الأهداف الفرعية التالية: • التعرف على مفهوم الإبداع في مكافحة الفساد الإداري وأنماط الفساد الإداري السائدة. • التعرف على أسباب الفساد الإداري. • التعرف على سبل التنمية المستدامة وأبعادها وأهدافها وسبل تحقيقها.

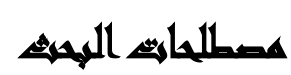

الابداع: أورد ابن منظور تفسيرا لكلمة إبداع وهي بدع، وبدع الثيء، مبتدعد، وابتداعه أي أنشأه واخترعه واستتبطه، والبدع الثيء الذي يكون أو لا يكون. التتميه المستدامه: تلبية احتياجات الأجيال الحالية دون الإضرار بقدرة الأجيال القادمة على

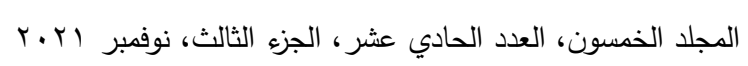

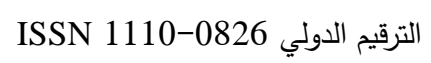

$$
\begin{aligned}
& \text { الترقيم الدولي الموحد الإكتروني 3178-2636 }
\end{aligned}
$$


الفساد: يعني أخذ المال ظلماً، أو يعني التلف والعطب ويراد به لغوياً الجدب والقحط، ويراد

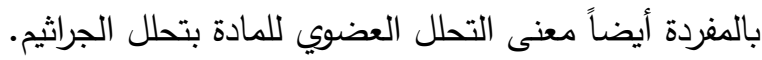

الفاسد: شخص غرضه الحصول على المال من الأشخاص مستغلاً موقعه الوظيفي بتبريرات قانونية أو إدارية أو إخفاء التعليمات النافذة على الأشخاص المعنيين كما يحدث في دوائر الثراص الضريبة أو تزوير الثهادة الدراسية أو تزوير النقود.

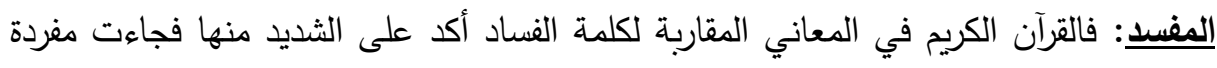

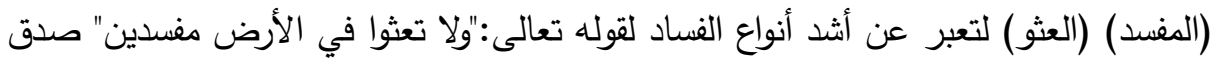
الله العظيم.

القائد فى الوظيفة العامة: تتضمن مجموعة العمليات القيادية والفنية عن طريق العمل

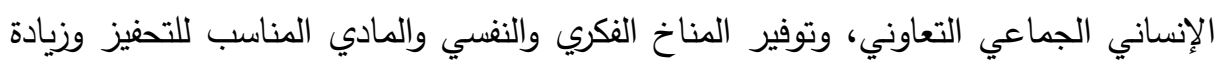
الرغبة، بالعمل المشترك والنشط والمنظم، والقدرة على التأثير لتوحيد الجهود الإنسانية واستثمار ولئي

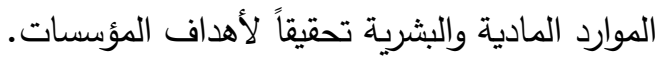

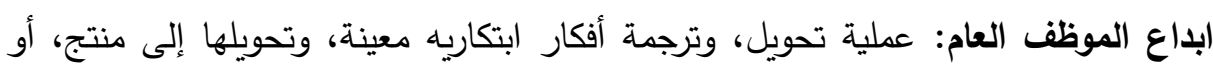

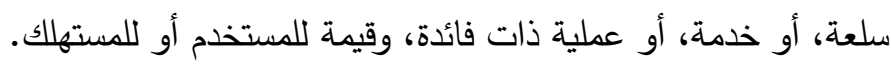

\section{السراسايت المربعهية}

دراسة المعمري، عبدالملك أحمد (r ا ـ r): اهداف الاراسة: التعرف على أبرز أثكال الفساد المالي والإداري في الجهاز الحكومي

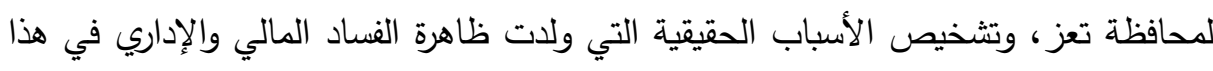
الجهاز، ووصف أثارها على التنمية ومن ثم وضع الحلول والمعالجات لها بما يساهم في تحقيق التتمية المرجوة وخدمة الوطن والمواطن. 216

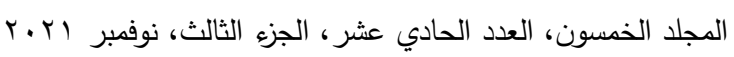

$$
\begin{aligned}
& \text { الترقيم الدولي 0826-0 تصني } \\
& \text { الترقيم الدولي الموحد الإكتروني 3178-2636 }
\end{aligned}
$$


نتائج الدراسة: من أكثر أشكال الفساد المالي والإداري انتثاراً في المؤسسات الحكومية في

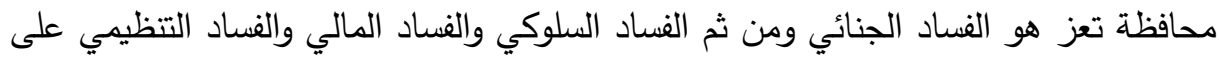

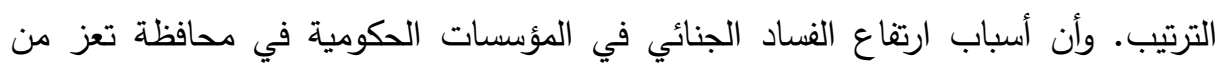
وجهة نظر العاملين فيها هي مظاهر: الرشوة، والابتزاز، والمحسوبية، والتزوير، ونهب الهبات المال

توصيات الاراسة: إعادة النظر في سياسات اختيار الأفراد وتعيينهم في الوظائف العامة بجعلها تقوم على أساس الكفاءة ومبدأ الجدارة والقضاء على الوساطة والدحسوبية والقبلية

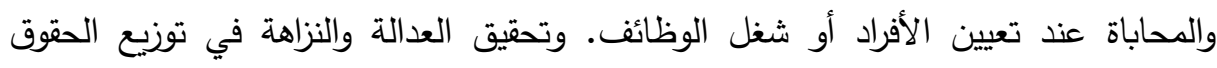
والواجبات، والتثديد على إعطاء الموظف العام حقوقه قبل مطالبته بأداء واجباته.

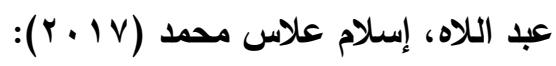

الهداف الدراسة: ويعتمد نجاح الهيئات الرياضية في تحقيق أهدافها بدرجة كبيرة على كفاءة

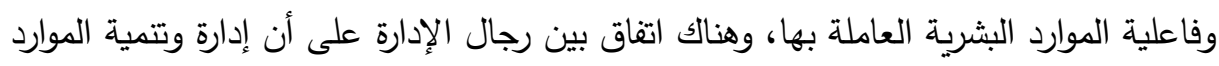

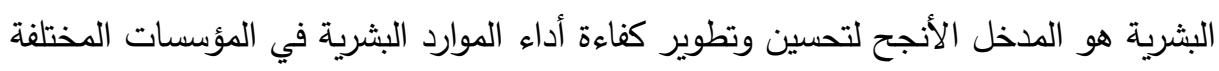
وذلك بما يحقق أعلي مستوي في الاداء لهذه المؤسسات. نتائج الدراسة: المفاهيم شأنها شأن المنتجات والتكنولوجيا لها دوره حياه، وأن كل مفهوم جديد منها يقدم مساهته الكبيرة فى معالجه المشكلات التى يساهم في حلها، ولكن سرعان مان التهات يصبح هذا المفهوم مصدراً لمشكلات جديده تستدعي جهوداً جديده. توصيات الاراسة: تتمية الإبداع حيث هو كل عمل جديد يستطيع الإنسان، صغيراً او كبيراً،

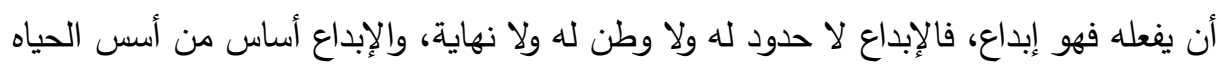

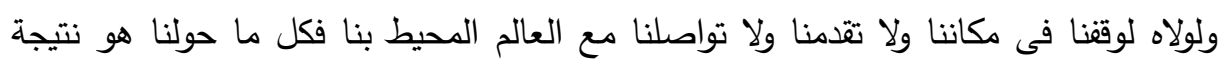

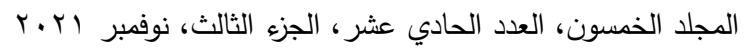

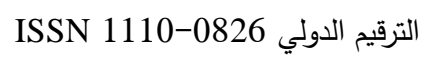

$$
\begin{aligned}
& \text { الترقيم الدولي الموحد الإلكتروني 3178-2636-26 }
\end{aligned}
$$


طبيعية للإبداع نعم كل ما حولنا سواء فى منازلنا أو فى شوارعنا هو ناتج عن عمليات إبداعية.

$$
\text { احمد، سمية حنفي حمدان (r. IV): }
$$

اهداف الدراسة: توضيح مفاهيم الإبداع والابتكار ومقوماته و أهية الإبداع و الابتكار الإداري

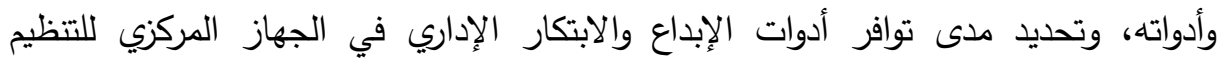

والإدارة والإمكانات أو المعوقات فى بيئة الجهاز المركزي للتتظيم والإدارة. نتائج الدراسة: الادارة لا تهتم بمكافأة السلوك الإبداعي وتوفير مناخ مناسب للإن للتعلم وتبادل

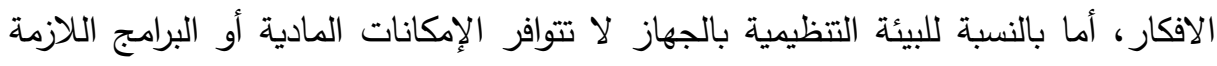
لتتمية الإبداع والحث على ممارسته، وبالنسبة للبيئة الثقافية والاجتماعية.

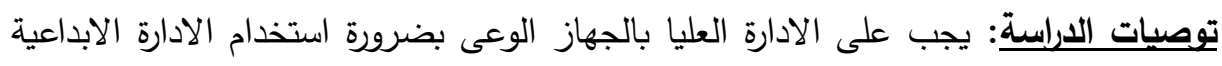

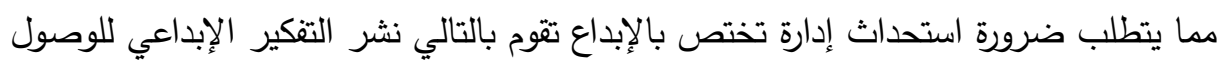

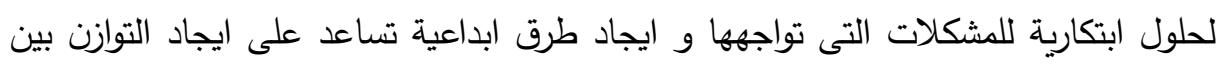

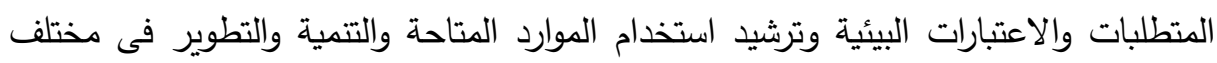
المجالات.

\section{رضوان، رغدة رضوان سعيد (Y IV)}

الهداف الدراسة: رفع وتحسين كفاءة الخدمة الجامعية من خلال الإبداع الإداري و استخدام الوسائل الحديثة للتعلم والابتكار مما يؤدى إلى تأهيل الطلبة بمواصفات مميزة.

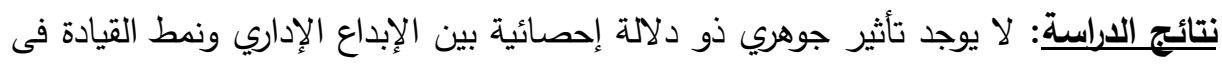

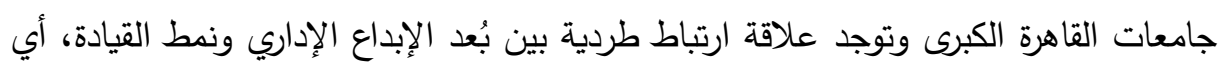
أنه بزيادة الاهتمام بالإبداع الإداري يؤدي هذا إلي زيادة جودة نمط القيادة، لذا فللإبداع الإداري تأثير كبير على أبعاد نمط القيادة ككل.

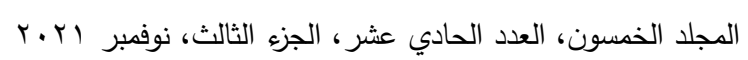

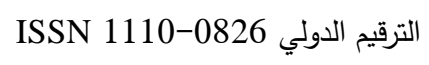

$$
\begin{aligned}
& \text { الترقيم الدولي الموحد الإكتروني 3178-2636-26 }
\end{aligned}
$$


توصيات الاراسة: نشاء إدارة حاضنة للإبداع أو إنشاء ما يسمى (بنك الأفكار ) تكون مسئولة عن دعم وتثجيع المبدعين والمتميزين.

Levent Altinay, (2020)

الهاف الدراسة: تأثير الجوانب العقلية للذكاء الثقافي من خلال الانفعالية على السلوك الإبداعي في ريادة الأعمال. باستخدام عينة من رواد الأعمال الناشئين في دولة نامية الإلية (كازاخستان).

نتائج الدراسة: هناك علاقة بين الذكاء الثقافي وإبداع رواد الأعمال. هناك علاقة بين العاطفة

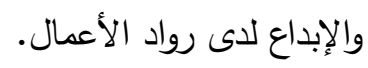
توصيات الدراسة: مهما ساعدتا التكنولوجيا في تحسين رضا العملاء، فإنّ القدرة على خلق الإبال علاقة عاطفية مع المستهلكين، سوف تكون العامل الرئيس الذي يميز المنافسة بين الشركات؛

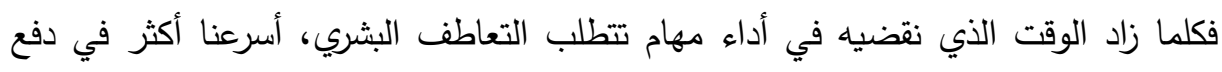
شركاتتا للأمام.

Youying Wang, Qian Huang, (2020)

الهداف الاراسة: كيفية تأثير ضغوط ادوار العمل على إبداع الموظف من خلال الاستكثاف

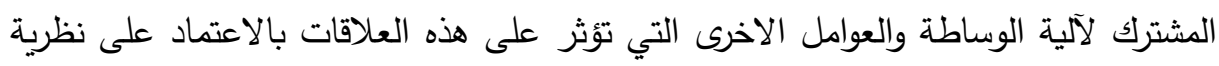

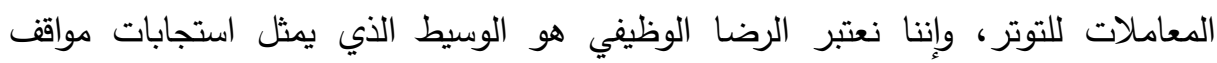
الموظفين للضغوط. نتائج الدراسية: يؤثر استخدام الوسائط الاجتماعية الموجه نحو المهام على دور ارتباط الرضا

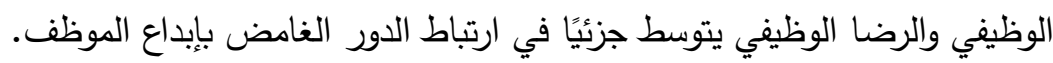

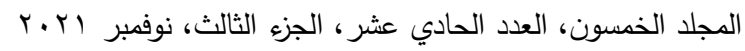

$$
\begin{aligned}
& \text { ISSN 1110-0826 الترقيم الدولي الدوني } \\
& \text { الترقيم الدولي الموحد الإلكتروني 3178-2636-26 }
\end{aligned}
$$


توصيات الارلسة: يجب اهتمام الجهات الرسمية بمدى رضا الموظف عن وظيفته وذلك لما له من ارتباط وثيق بالجانب الإبداعي وخاصة ما تعلق بالأجر والترقية والذي وجد فيهما رضا وظيفي منخفض.

Xiayu Chen, (2020)

اهداف الدراسية: كيف تؤثر شفافية الرسائل وشفافية التواصل على مشاركة معارف الموظفين وإخفائها، وبالتالي كيف ترتبط هذه بإبداع الموظفين وذلك من خلال تطبيق نظرية التركيز التنظيمي. نتائج الدراسة: تئثر شفافية الرسائل بشكل إيجابي على مشاركة المعرفة. تؤثر شفافية التواصل بشكل إيجابي على مشاركة المعرفة والاختباء. توصيات الاراسة: الاستثمار في الموجودات الفكرية والمعرفية غير الملموسة اكثر من تركيزه

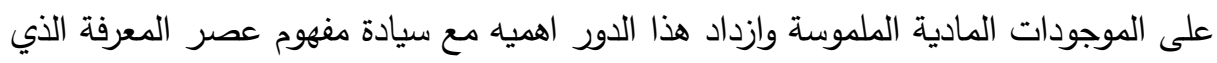
من متطلباته الا تكتفي المنظمات بتوفير المعلومات.

\section{هروض الهمهي}

الفرض الاول: توجد علاقة ارتباط جوهرية بين الابداع ونظم مكافحة الفساد. الفرض الثانى: توجد علاقة ارتباط جوهرية بين تأثير الابداع و جودة نمط القيادة فيط الهئ الهياكل التنظيمية الحكومية. الفرضية الثالثة: توجد علاقة ارتباط جوهرية تبنى الابداع وتحقيق التتمية المستدامة تعزي

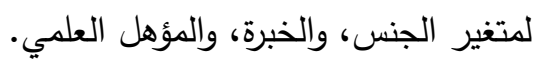

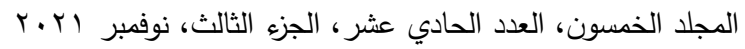

$$
\begin{aligned}
& \text { الترقيم الدولي 0826-0 تصني } \\
& \text { الترقيم الدولي الموحد الإكتروني 3178-2636 }
\end{aligned}
$$




\section{الاطال اللنظلرى}

يلعب الإبداع دور هام في بقاء المنظمات وتطورها في ظل التحديات العالمية، كما انه

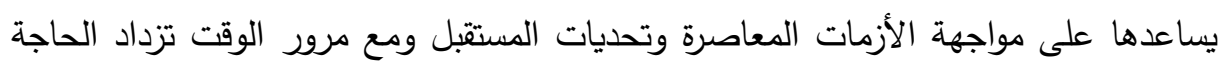
للإبداع، إذ أننا نعيش في عالم يتلاحق فيه النمو وتزداد المتغيرات، مما يستوجب على الإتى الجميع

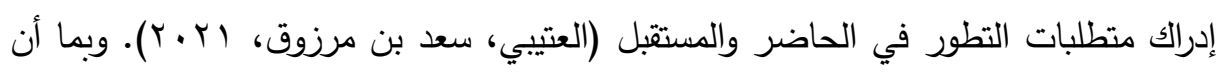

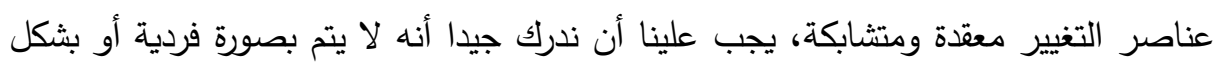
جزئي، بل يجب أن ينطلق في إطار متكامل ومحدد بدقة علمية ومنهجية، والإبداع في

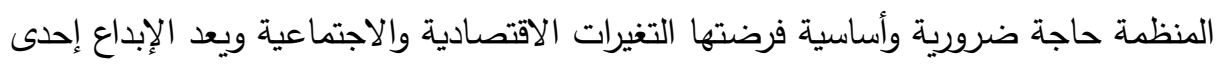

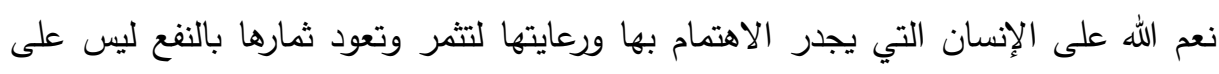
صاحبها وحده، بل على المجتمع ككل وهو ما يستلزم ضرورة معرفة طرق الإنس اكتثافها

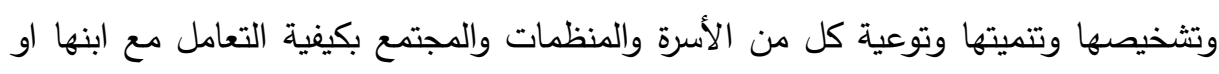
موظفيها المبدعون ورعايتهم، وأهمية تذليل العقبات التي تواجه الكثف عن عن أبنائه المبدعون

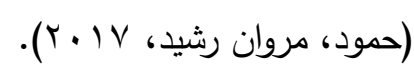

إن الفساد (Corruption) مصطلح يتضمن معاني عديدة في طياته، والفساد موجود في

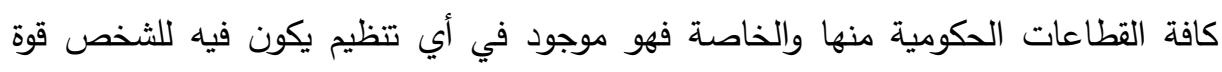
مسيطرة أو قوة احتكار على سلعة أو خدمة أو صاحب قرار وتكون هنالك حرية في تحديد الأفراد الذين يستلمون الخدمة أو السلعة أو تمرير القرار لفئة دون الأخرى وقد الفئ يتضمن

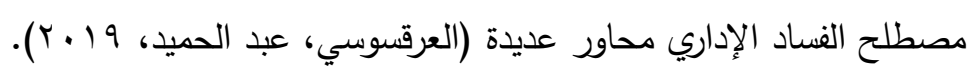

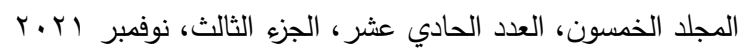

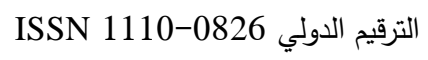

$$
\begin{aligned}
& \text { الترقيم الدولي الموحد الإلكتروني 3178-2636-26 }
\end{aligned}
$$




\begin{abstract}
اجراءات الاراسة: أسلوب معالجة وتحليل البيانات: لتحقيق أهداف البحث، فقد تم تحليل البيانات التي تم جمعها

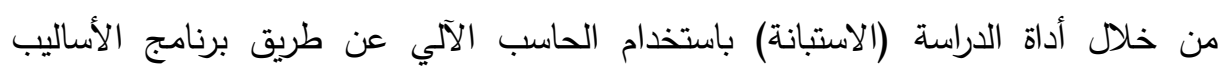

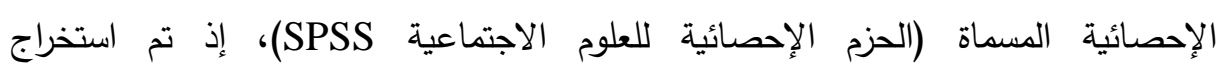

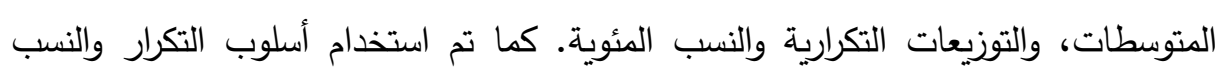
المئوية لتبيان نسب الموافقة في الاستجابات.

مجتمع الدراسة: مجتمع الدراسة يتكون من موظفي الخدمة العامة في محافظ القاهرة وتم التحابتان

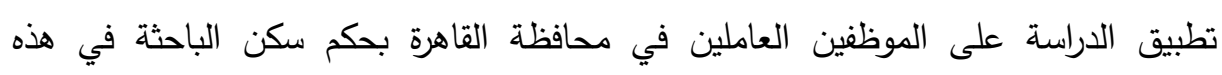

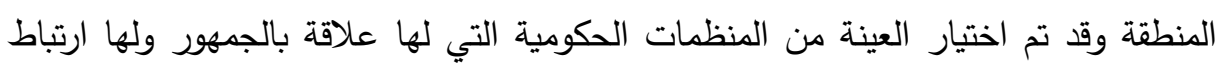
واضح بالتعاملات اليومية للمواطن والمقيم وتثار حولها العديد من الملاحظات، وهي (الديوان

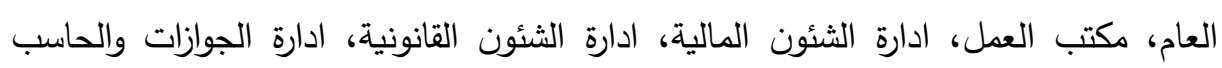
الألى، ادارة المرور والرخص)، بالإضافة إلى بعض المهتمين بالمجالات البيئية.
\end{abstract}


جدول (1): جدول معامل ثبات ألفا كرونباخ لأجزاء الاستبانة

\begin{tabular}{|c|c|}
\hline قيمة ألفا & 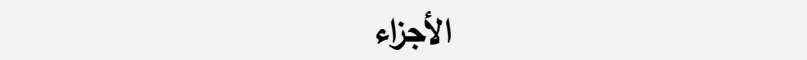 \\
\hline & مقاييس المحاور \\
\hline$\cdot, \wedge \mathrm{V}$ & الابداع وعلاقتها بنظم مكافحة الفساد \\
\hline$\cdot, \wedge$ & تأثير الابداع على جودة نمط القيادة فى الهياكل التنظيمية الحكومية \\
\hline \multirow[t]{2}{*}{$\cdot, 91$} & تبنى الابداع لتحقيق التتمية المستدامة \\
\hline & المقاييس الأخرى \\
\hline$\cdot, 9$. & مدى ثقته في بعض المؤسسات والخذمات الحكومية \\
\hline$\cdot, 91$ & مدى الرضا عن بعض المؤسسات والخدمات الحكومية \\
\hline$\cdot, r \cdot$ & جهود الحكومة في محاربة الفساد \\
\hline$\cdot, 9$ & مقاييس الفساد الكلي \\
\hline
\end{tabular}

تظهر مقاييس الفساد ثباتاً عالياً منفردة ومجتمعة، كما إن بقية المقاييس تمتعت بثات

عال باستثناء مقياس جهود الحكومة.

منهج البحث: المنهج الوصفي التحليلي: مجموعة الإجراءات البحثية التي تتكامل لوصف الظاهرة أو الموضوع اعتماداً على جمع الحقائق والبيانات وتصنيفها ومعالجتها وتحليلها تحليلاً

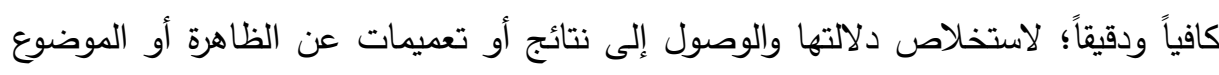
محل البحث.

مصادر جمع البيانات: مصادر أولية: تتمثل في استمارة الاستقصاء والمقابلة الثخصية لتوزيع وجمع الاستمارات... وذلك في الفترة الزمنية .ب.r.r وذلك فى مجتمع العاملين والقيادات فى ديوام محافظة القاهرة وبعد مراجعة مشكلة الدراسة وفرضياتها قام الباحثون

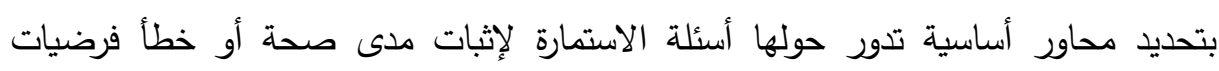

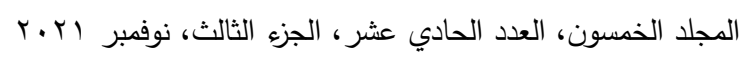

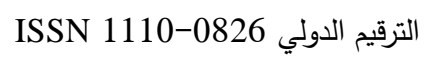

$$
\begin{aligned}
& \text { الترقيم الدولي الموحد الإكتروني 3178-2636-26 }
\end{aligned}
$$


الدراسة، قام الباحثون بإرفاق خطاب للمبحوثين تم فيه شرح موضوع الدراسة هدفها وغرضها، وقد روعي في بناء الاستبانة الشروط الأولية في بناء الدقاييس وهي:

الموضوعية: حيث قام الباحثون بتوحيد إجراءات التطبيق من حيث وضوح التهاء التعليمات، وتحديد زمن الإجابة، وطريقة التصحيح. الثمول: راع الباحثون أن يشتمل المقياس مستويات عقلية متباينة للمبحوثين.

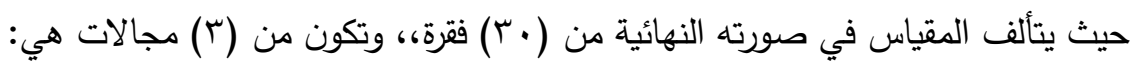

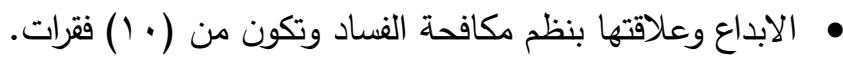

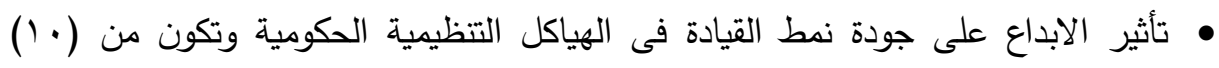
فقرات. • تبنى الابداع لتحقيق التنمية المستدامة وتكون من (• () فقرات. الأساليب الإحصائية المستخدمة: صدق الاستبانة: يقصد بصدق أداة الدراسة الميدانية صدق تفسيرات نتائج الدراسة وإمكانية

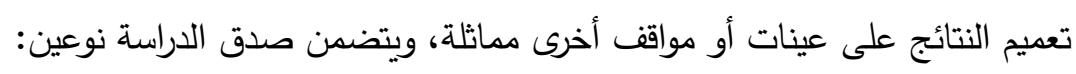
الصدق الداخلي Internal Validity ويقصد به أن نتائج الدراسة تُعزى إلى المتغيرات موضوع القياس أو المعالجة المرتبطة بأهداف الدراسة.

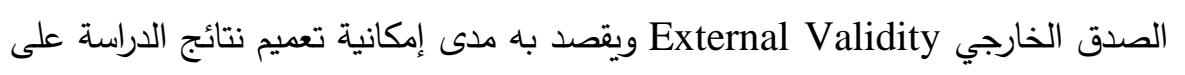
عينات أو مواقف أخرى.

ولقد اعتمد الباحثون من تحديد صدق الاستبانة على الصدق الظاهرى (صدق الطق المحكمين)، حيث تم عرض الاستبانة على مجموعة من المحكمين وذلك بهدف التأكد من

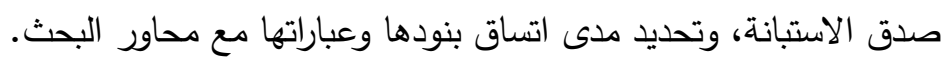

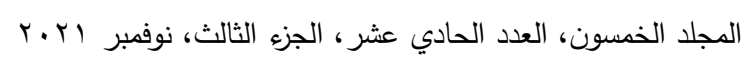

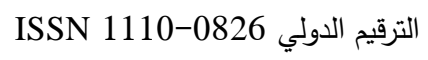

$$
\begin{aligned}
& \text { الترقيم الدولي الموحد الإكتروني 3178-2636-26 }
\end{aligned}
$$


ثبات الاستبانة: وقد تم حساب معامل الثبات باستخدام معادلة " ألف كرونباخ" حيث إنها طريقة لحساب الأوزان المستخدمة في البحوث المسحية، حيث يوجد مدى من الدرجات المختلفة لكل كور ، وذلك وفقاً للمعادلة الآتية (أبو علام رجاء محمود 991 (1) )

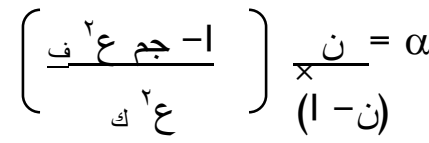

$$
\begin{aligned}
& \text { حيث م= معامل الثبات. } \\
& \text { ع ع ف = تباين الفترة الواحدة من الاستبانة. } \\
& \text { ع ك ك = التباين الكلى للاستبانة. }
\end{aligned}
$$

سوف يعتمد الباحثون على المنهج الوصفي والكمي وذلك باستخدام مجموعة من الأساليب والمؤشرات الإحصائية التي تخدم أهداف البحث، كما يلي: مقاييس الإحصاء الوصفي والكمي: يتم استخدام بعض المقاييس الإحصائية الوصفية والكمية الإنية

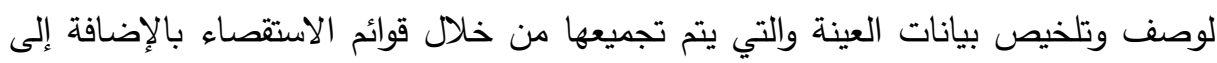
تصور بعض خصائص العينة والاستدلال على خصائص المجتمع ومن أمثلة تلك المقاييس التكرارات، النسب المئوية، المتوسط الحسابي، الانحراف المعياري. حدود البحث: يقوم الباحثون بتناول دراسة دور الإبداع في مكافحة الفساد الإداري لتحقيق الإن التتمية المستدامة بالمنظمات الحكومية (ديوان محافظة القاهرة) وفق الحدود التالية: تقتصر العينة محل البحث والدراسة الميدانية على تقتصر الدراسة على الحدود التالية:

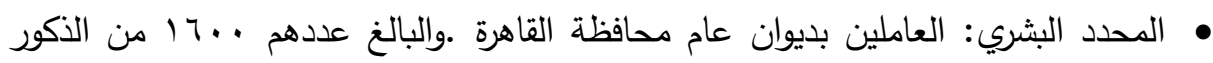
والإناث.

• المحدد المكاني: ديوان عام محافظة القاهرة وعدد من ادارات الاحياء التابع له.

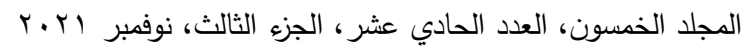

$$
\begin{aligned}
& \text { ISSN 1110-0826 الترقيم الدولي الدوني } \\
& \text { الترقيم الدولي الموحد الإلكتروني 3178-2636-26 }
\end{aligned}
$$




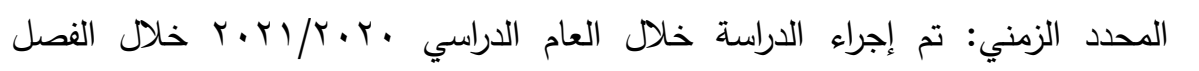

$$
\text { الدراسي الثاني }
$$

•المحدد الموضوعي: تحدد نتائج الدراسة جزئي أو كلي بالأدوات والإجراءات المستخدمة

$$
\text { لجميع البيانات وتحليله. }
$$

• المحدد المفهومي: تتحدد نتائج الدراسة بموضوعها المتعلق بتقييم واقع الدور الذي يقوم به الابداع البشرى في مقاومة الفساد واثر ذلك في التتمية المستدامة من خلال رؤية ميدانية

للعاملين بديوان عام محافظة القاهرة.

\section{المئمائم}

بعد دراسة الباحثون لدارسة الإطار النظري دور الإبداع في مكافحة الفساد الإداري

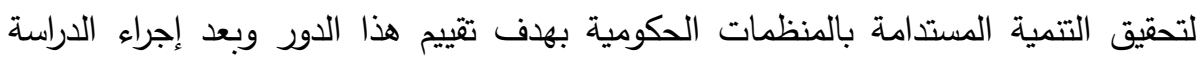
الميدانية تخلص إلى النتائج التالية: • ت تثير النتائج إلى عدم وجود فرق ذي دلالة إحصائية عند مستوى الدلالة (a بين المتوسطين الحسابيين لإجابات أفراد عينة الدراسة تبعاً لمتغير الجنس في أي مجال من المجالات الدراسة وذلك قد يعود إلى أن تقارب مستويات الفكر بين الذكور والإناث نظراً لتشابه طرق تتمية الإبداع عند الذكور والإناث. • تثير النتائج إلى عدم وجود فرق ذي دلالمة إحصائية عند مستوى الدلالة (a

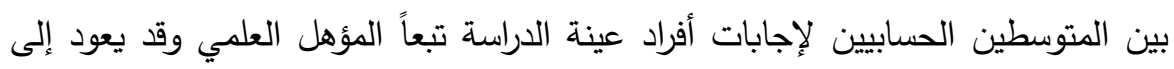
اتفاق المديرون والعاملين في مبنى محافظة القاهرة من ذوي المؤهلات العلمية المختلفة

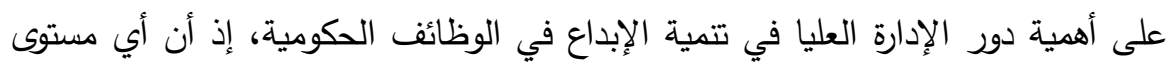

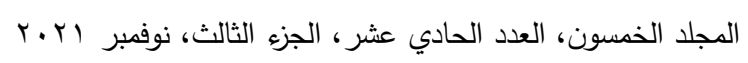

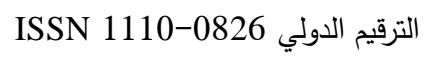

$$
\begin{aligned}
& \text { الترقيم الدولي الموحد الإكتروني 3178-2636 }
\end{aligned}
$$




$$
\begin{aligned}
& \text { مجلة العلوم البيئية } \\
& \text { كلية الدراسات العليا والبحوث البيئية - جامعة عين شمس البية } \\
& \text { غدير مدحت محمد وآخرون }
\end{aligned}
$$

من التأهيل العلمي يصل بصاحبه إلى الاقتتاع بأهمية دور الإدارة العليا في تتمية الإبداع في الوظيفة.

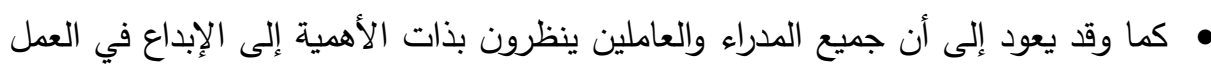

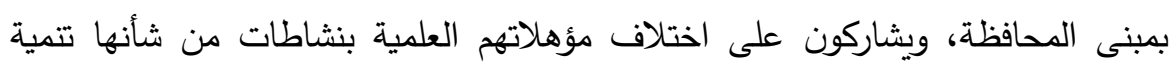
الإبداع في مبنى محافظة القاهرة.

واقع الاهتمام بتنمية الابداع وعلاقته بنظم مكافحة الفساد: تم حساب المتوسطات

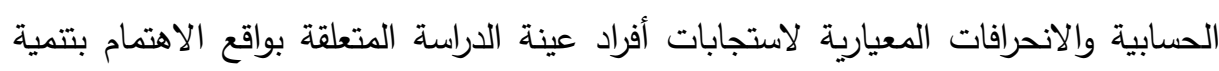

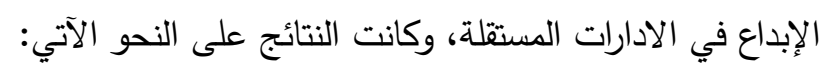

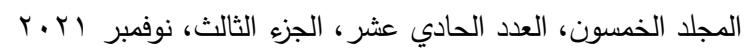

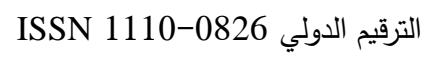

$$
\begin{aligned}
& \text { الترقيم الدولي الموحد الإلكتروني 3178-2636-26 }
\end{aligned}
$$


مجلة العلوم البيئية

كلية الدراسات العليا والبحوث البيئية - جامعة عين شمس لائة

غدير مدحت محمد وآخرون

جدول (Y): المتوسطات الحسابية والانحرافات المعيارية لفقرات واقع الاهتمام بتتمية الابداع وعلاقته بنظم مكافحة الفساد

\begin{tabular}{|c|c|c|c|c|c|}
\hline ال الموافقة & 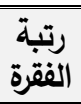 & 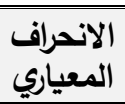 & المتوسط & 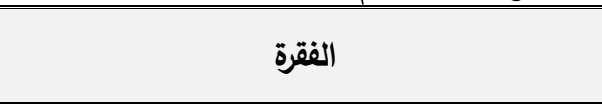 & 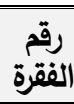 \\
\hline 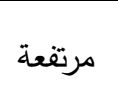 & 1 & 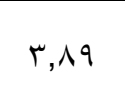 & $\{, 77$ & ما رايك أن استطعت حل متريقة المشاكل إذا أتبعت & $r$ \\
\hline 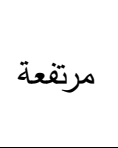 & r & $\cdot, 74$ & $\varepsilon, \mu r$ & 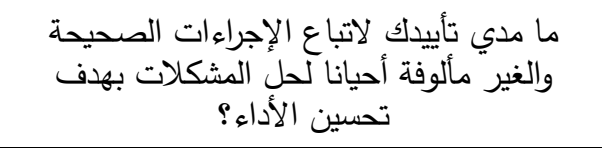 & 1 \\
\hline 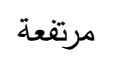 & r & $\cdot$ & $\varepsilon, 1 V$ & مفهومك للفساد الإداري؟ السرقات والاختلاسات. & $\varepsilon$ \\
\hline 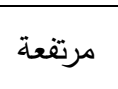 & 0 & $\cdot, \vee \wedge$ & $\varepsilon, 1 T$ & أتأني في تتظيم المعلومات التي أجمعها لأخرجها & 0 \\
\hline 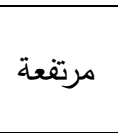 & 0 & $\cdot, \vee \wedge$ & $\varepsilon, 1 T$ & 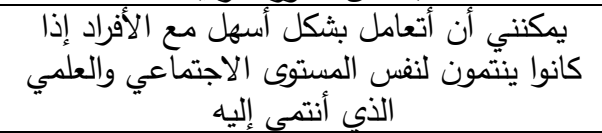 & 7 \\
\hline 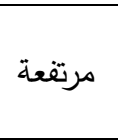 & 7 & $\cdot, 99$ & $\varepsilon, \cdot \varepsilon$ & 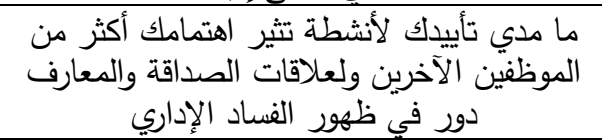 & r \\
\hline 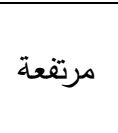 & V & • & $\varepsilon, \cdot 1$ & 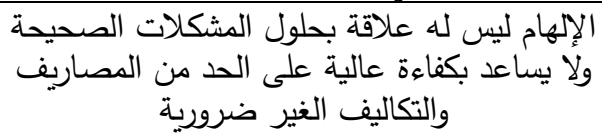 & V \\
\hline 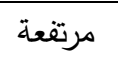 & $\wedge$ & $\cdot, \wedge т$ & $r, 90$ & دوافع الفساد الإداري؟ القرابة في العمل & 1. \\
\hline 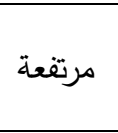 & 9 & $\cdot, 91$ & r,Ar & 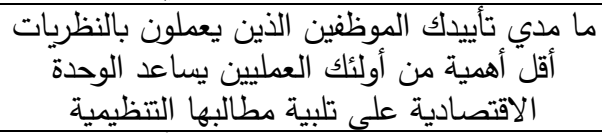 & 9 \\
\hline متوسطة & 1. & 1,11 & $r, q$ & 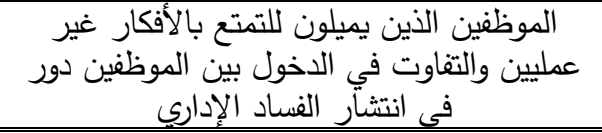 & $\wedge$ \\
\hline
\end{tabular}

الترقيم الدولي الموحد الإكتروني 3178-2636 
تم حساب المتوسطات الحسابية والانحرافات المعيارية لكل فقرة من فقرات المجال الثاني من مجالات أداة الدراسة، وقد جاء المتوسط الحسابي للمجال (r.,.؟) وبانحراف معياري

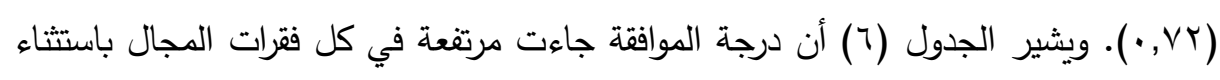

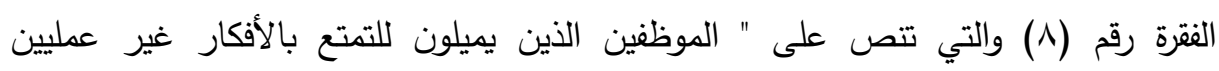

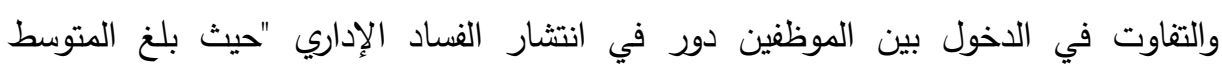

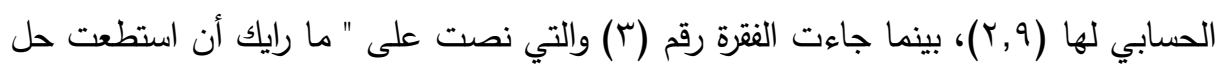

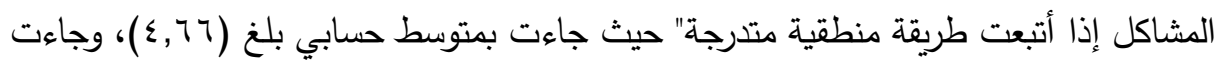

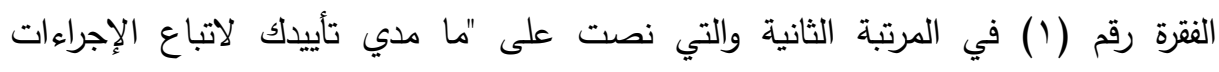

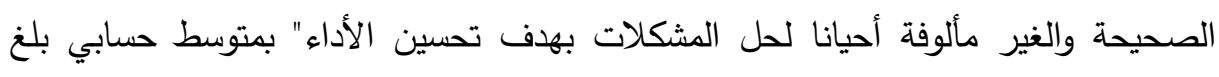

دور تأثير الابداع على جودة نمط القيادة فى الهياكل التنظيمية الحكومية: تم حساب المتوسطات الحسابية والانحرافات المعيارية لاستجابات أفراد عينة الدراسة وكانت

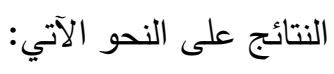

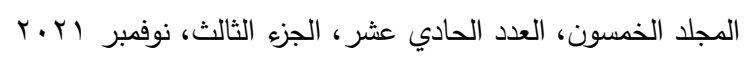

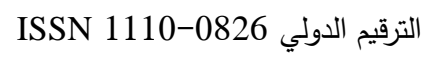

$$
\begin{aligned}
& \text { الترقيم الدولي الموحد الإكتروني 3178-2636-26 }
\end{aligned}
$$


جدول (ץ): المتوسطات الحسابية والانحرافات المعيارية لفقرات واقع تأثير الابداع على جودة

\begin{tabular}{|c|c|c|c|c|c|}
\hline الموافقة & رتبة & 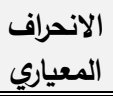 & المتوسط & الفقرة & رقفر \\
\hline مرتقعة & 1 & • & $\varepsilon, \varepsilon \vee$ & 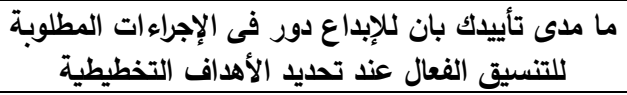 & r \\
\hline مرتقعة & $r$ & $\cdot, \wedge \wedge$ & $\varepsilon, T Y$ & 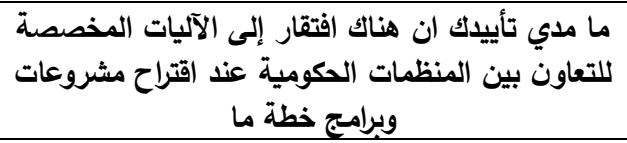 & 0 \\
\hline مرتفعة & r & $\cdot, \vee 7$ & $\varepsilon, M_{1}$ & يمكنها ابتكار أساليب مناك افتقار للكوادر الفنية المدربة التيق التحقيق التعاون بين هذه & $\varepsilon$ \\
\hline مرتقعة & $\varepsilon$ & $\cdot, \wedge \wedge$ & $\varepsilon, Y_{Y}$ & ما رايك ان هناك نقص التمويل اللازم لتنفيذ برامج خطة & 9 \\
\hline مرتقعة & $\varepsilon$ & $\cdot, \wedge 0$ & $\varepsilon, Y_{T}$ & 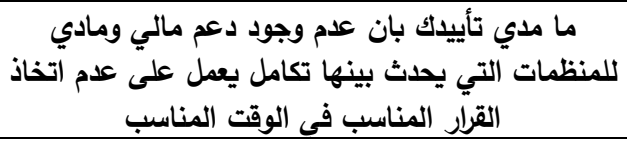 & 1. \\
\hline مرتقعة & 0 & $\cdot, \Lambda$ & $\varepsilon, Y \varepsilon$ & 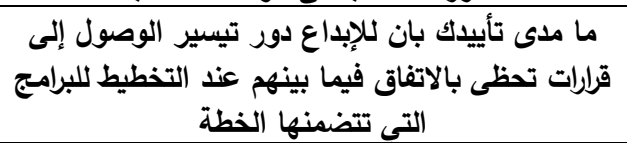 & $r$ \\
\hline مرتقعة & 7 & $\cdot, \wedge \wedge$ & $\varepsilon, Y_{1}$ & ما لمسئولين للقيام للإبداع دور فئ علاج التنسيق عند وضع الخبرة & 1 \\
\hline مرتقعة & 7 & • • & $\left\{, Y_{1}\right.$ & 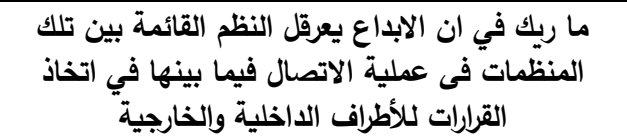 & 7 \\
\hline مرتقعة & V & .,95 & $\Gamma, \wedge \wedge$ & 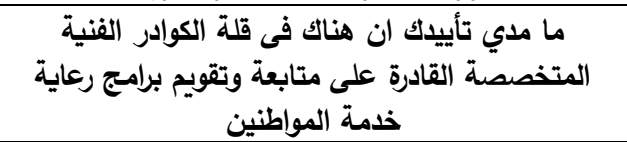 & $\Lambda$ \\
\hline مرتقعة & $\wedge$ & $\cdot, 10$ & r, ^ & 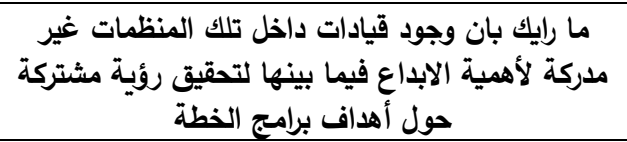 & V \\
\hline
\end{tabular}

$$
\begin{aligned}
& \text { المجلد الخمسون، العدد الحادي عشر ، الجزء الثالث، نوفمبر اب.r }
\end{aligned}
$$

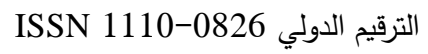

$$
\begin{aligned}
& \text { الترقيم الدولي الموحد الإكتروني 3178-2636 }
\end{aligned}
$$


تم حساب المتوسطات الحسابية والانحرافات المعيارية لكل فقرة من فقرات المحور الثاني

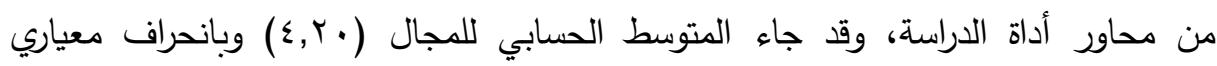

ويشير جدول (r) أن درجة الموافقة جاءت مرتفعة في كل فقرات المجال حيث جاءت

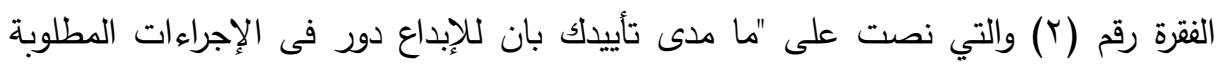

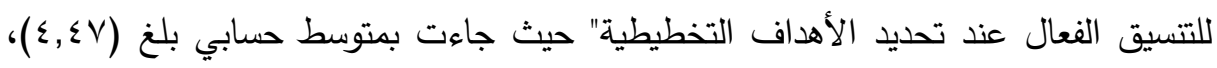

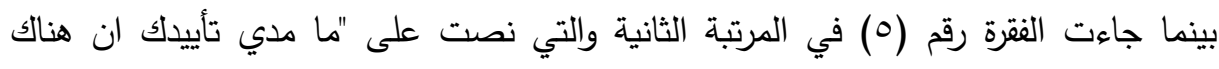
افتقار إلى الآليات المخصصة للتعاون بين المنظمات الحكومية عند اقتراح مشروعات وبرامج

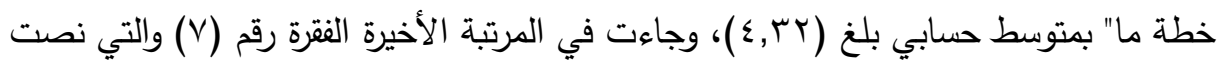

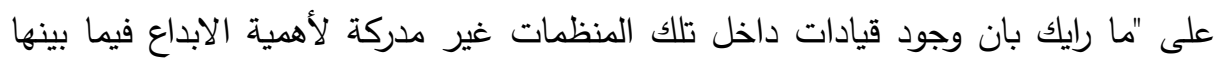

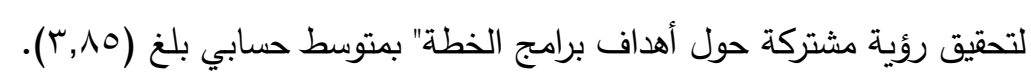
النتائج المتعلقة تبنى الابداع لتحقيق التنمية المستدامة: تم حساب المتوسطات الحسابية والانحرافات المعيارية لاستجابات أفراد عينة الدراسة وكانت النتيجة على النحو 
مجلة العلوم البيئية

كلية الدراسات العليا والبحوث البيئية - جامعة عين شمس لبئة

غدير مدحت محمد وآخرون

جدول (؛): المتوسطات الحسابية والانحرافات المعيارية لفقرات تبنى الابداع لتحقيق التتمية

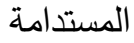

\begin{tabular}{|c|c|c|c|c|c|}
\hline الموافقة & رتبقة & الانحراف & المتوبط الحسبي & الفقرة & الفقرة \\
\hline منخفضة & r & $1, r r$ & $r, 09$ & ما مالمشاركة تأييدك بان توفير أجواء التعاون & $r$ \\
\hline منخفضة & $r$ & $1, Y 1$ & Y,OV & ما ورايك ان المشاركة في دورات تدربيية & r \\
\hline منخفضة & $\varepsilon$ & $\Gamma, \wedge \varepsilon$ & $Y, 0 \leqslant$ & ما مدي تأييداك ان الالتزام بالمعايير & 7 \\
\hline منخفضة & 0 & $1, r \varepsilon$ & $r, 01$ & الاعمال بأنشطة ومان تشجا القيادة وحقائقى إبداعية. & 1 \\
\hline منخفضة & 7 & $1, r$ & $r, \Sigma Y$ & ما مدي رايك في وجود نظام تكنولوجي & $\varepsilon$ \\
\hline منخفضة & V & 1,10 & $Y, \Sigma$ & ما مدي رايك بان وجود نظام إداري مرنا & 0 \\
\hline منخفضة & $\wedge$ & $1,1 \leq$ & r,ru & يصب في رايك ان تطبيق مبادئ الاستدامة الوحدة الاقتصادية & $1 \cdot$ \\
\hline منخفضة & 9 & $1,1 \leq$ & $r, Y V$ & 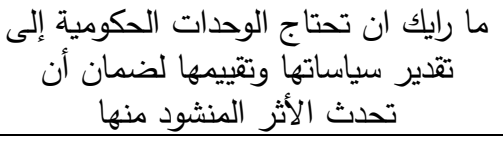 & $\wedge$ \\
\hline منخفضة & $1 \cdot$ & 1,17 & $r, Y r$ & 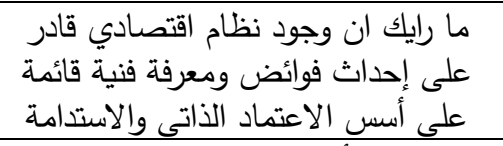 & V \\
\hline منخفضة & $1 \cdot$ & $1,1 \pi$ & $r, 1 T$ & الاستدامة قدي تأييدك أن الداء الوحدة الاقتصاد تقارير & 9 \\
\hline
\end{tabular}

$$
\begin{aligned}
& \text { المجلد الخمسون، العدد الحادي عشر ، الجزء الثالث، نوفمبر اب.r } \\
& \text { الترقيم الدولي 0826-0 تصدي } \\
& \text { الترقيم الدولي الموحد الإكتروني 3178-2636 }
\end{aligned}
$$


تم حساب المتوسطات الحسابية والانحرافات المعيارية لكل فقرة من فقرات المحور الثالث

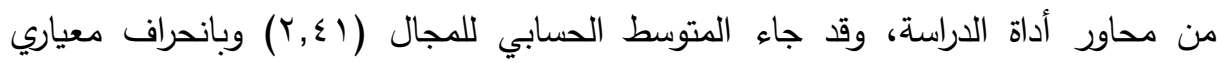
$\cdot(1,+1)$

ويشير جدول (ع) أن درجة الموافقة جاءت بين متوسطة ومنخفضة في كل فقرات

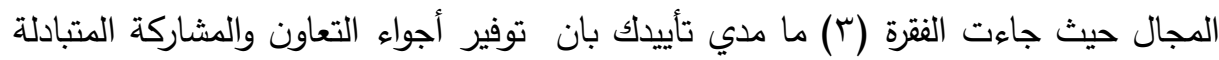
بين العاملين والإدارة يؤدى الى رفع طاقة العمل، في المرتبة الأولى بمتوسط (باء)، يليه الفقرة

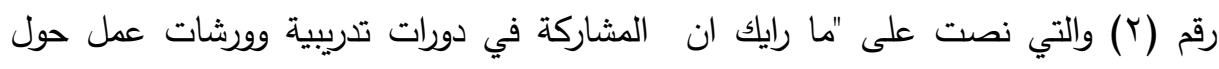

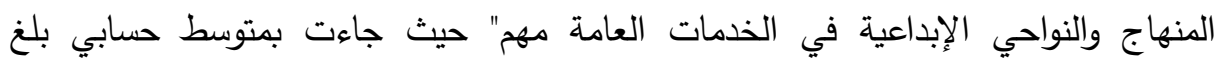

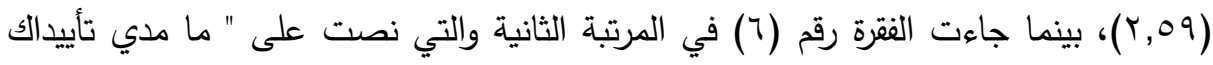
ان الالتزام بالدعايير ووجود نظام سياسي يؤمن المشاركة الفعالة للمواطنين في صنع القراء

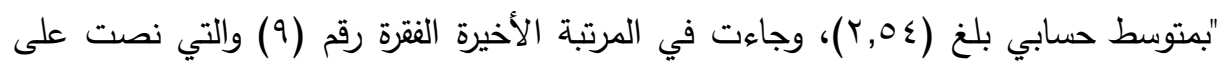

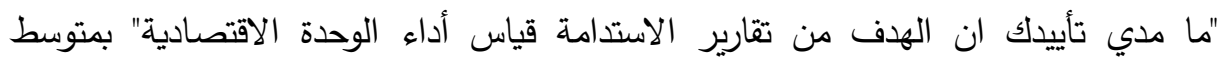

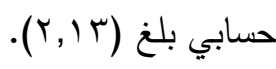

\section{الميوكياته}

خرج الباحثين بمجموعة من التوصيات اعتماداً على النتائج التي توصلت إليها الدراسة وهي:

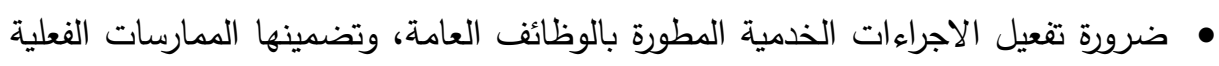
للعاملين الموهوبين يدعو إلى تتمية الإبداع بناء على الفروقات الفردية لتقوم بدورها في تتمية الإبداع في الوظائف في محافظة القاهرة على صعيد المدراء والعاملين.

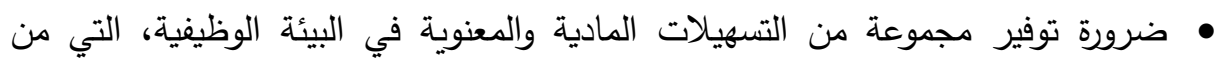
شأنها تعزيز النمو الإبداعي لدى العاملين ومتلقى الخدمات.

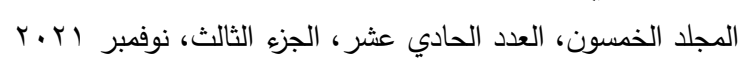

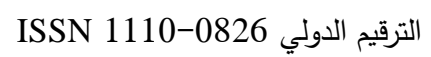

$$
\begin{aligned}
& \text { الترقيم الدولي الموحد الإكتروني 3178-2636 }
\end{aligned}
$$


• ضرورة استحداث منسق متخصص في الإبداع والموهبة في كل مجموعة وظيفية للقيام بإعداد البرامج الإثرائية لهؤلاء العاملين بالإضافة لتقديم الدعم والتوجيه للعاملين.

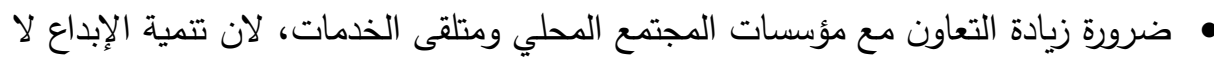
تقتصر فقط على الوظائف والموظفين، حيث يؤدي المجتمع المحلي دورا مهما في سبيل خلق بيئة مشجعة للإبداع. • ضرورة إعداد الدورات التأهيلية للعاملين بمحافظة القاهرة في برامج الإبداع والموهبة.

\section{المرانج}

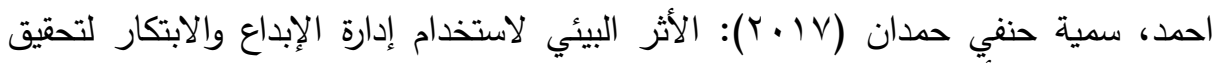

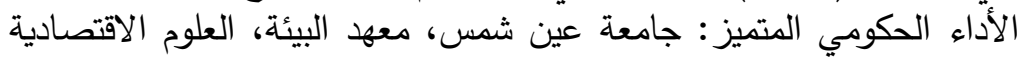

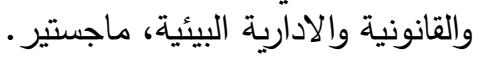

أسامة خيري (Y ( • ( ) إدارة الإبداع والابتكارات، دار الراية للنشر والتوزيع، عمان، الأردن.

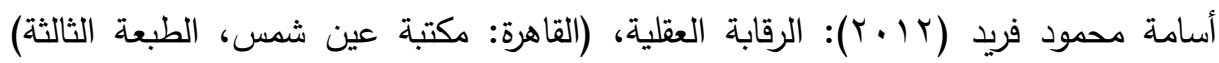

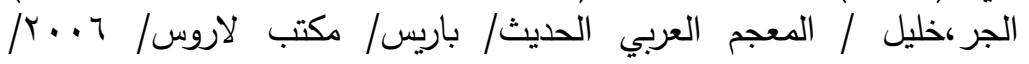

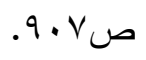

حسن، محمد قدري (0 . ب): الفساد الإداري. الفكر الثرطي: القيادة العامة لثرطة الثارقة -

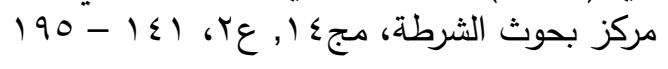

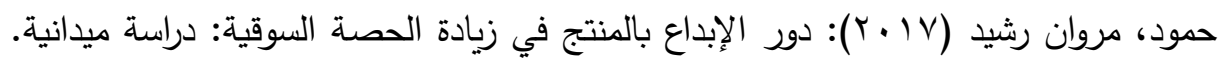

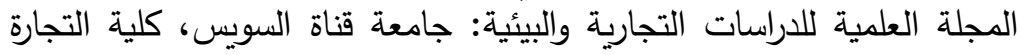

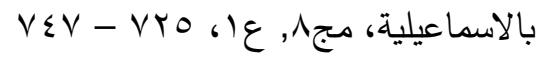

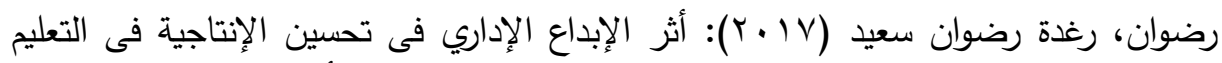

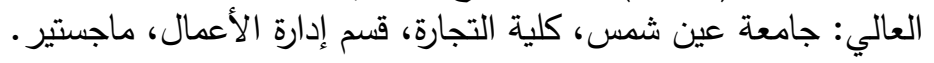

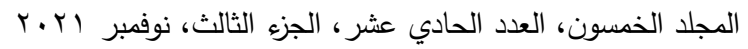

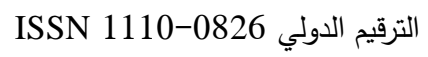

$$
\begin{aligned}
& \text { الترقيم الدولي الموحد الإلكتروني 3178-2636-26 }
\end{aligned}
$$




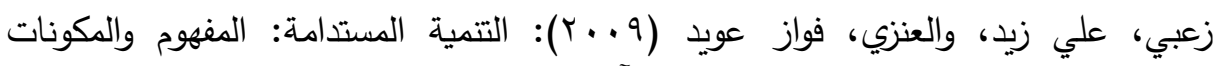
ومؤشرات القياس. حوليات آداب عين شمس: جال جامعة عين شمس، كلية

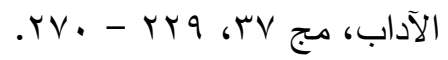

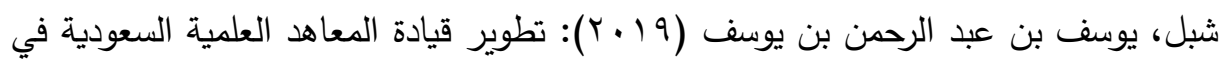

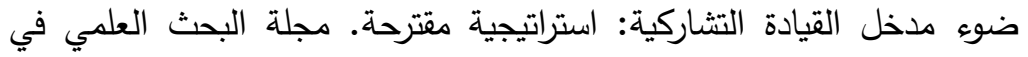

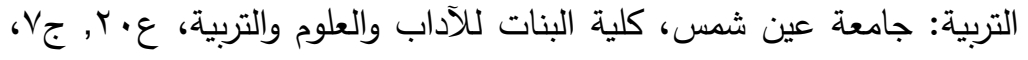

$$
.191-171
$$

عبد اللاه، إسلام علاس محمد (Y V V V): الإبداع الإداري وعلاقتته بإدارة الأزمات لإى العاملين

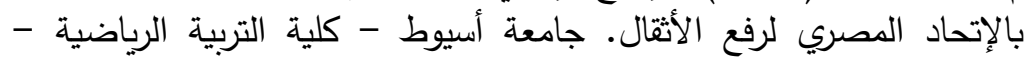

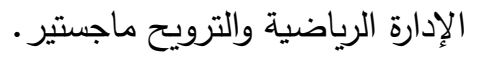

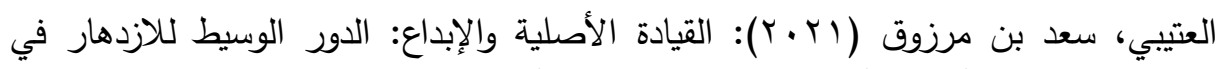

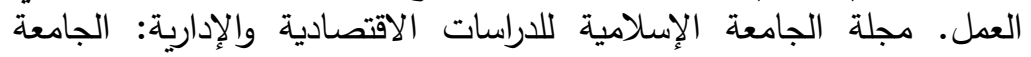

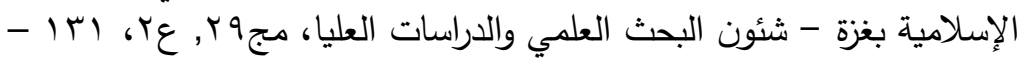
10r

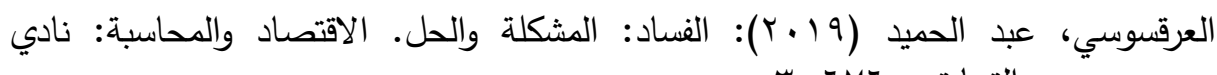

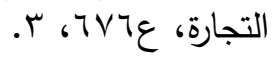

$$
\text { القرآن الكريم/سورة البقرة/ الآية ( • (؟). }
$$

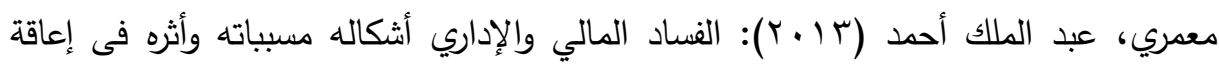

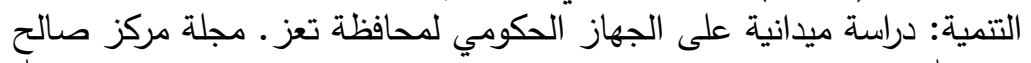

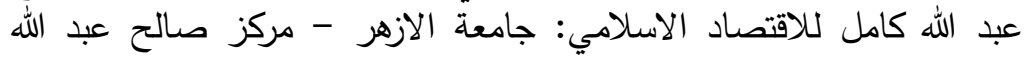

$$
\text { كامل للاقتصاد الإسلامي. }
$$

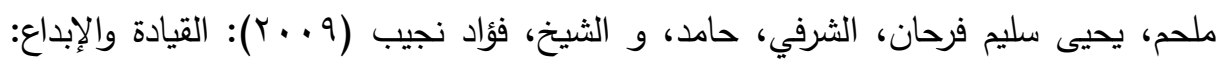

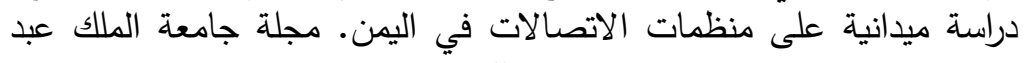

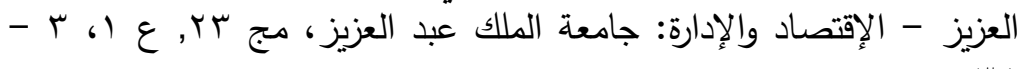

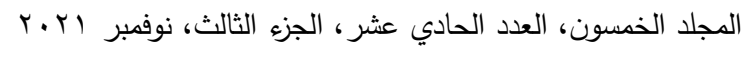

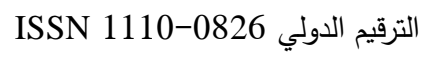

$$
\begin{aligned}
& \text { الترقيم الدولي الموحد الإكتروني 3178-2636-26 }
\end{aligned}
$$




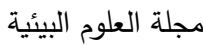

$$
\begin{aligned}
& \text { كلية الدراسات العليا والبحوث البيئية - جامعة عين شمس للئس } \\
& \text { غدير مدحت محمد وآخرون }
\end{aligned}
$$

مددوح الحيطى، ظاهرة الفساد وانعكاساتها الاجتماعية على عملية التتمية قراءة سوسيولوجية

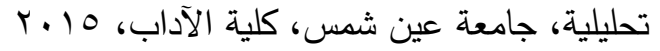

Levent Altinay, Gulsevim Kinali Madanoglu, Endrit Kromidha, Armiyash Nurmagambetova, Melih Madanoglu (2020): Mental aspects of cultural intelligence and self-creativity of nascent entrepreneurs: The mediating role of emotionality, Journal of Business Research

Xiayu Chen, Shaobo Wei, Ronald E. (2020): Rice, Integrating the bright and dark sides of communication visibility for knowledge management and creativity: The moderating role of regulatory focus, Computers in Human Behavior, Volume 111.

Youying Wang, Qian Huang, Robert M. Davison, Feng Yang, (2020): Role stressors, job satisfaction, and employee creativity: The cross-level moderating role of social media use within teams, Information \& Management.

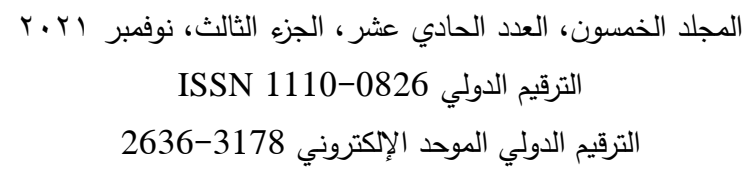




$$
\begin{aligned}
& \text { مجلة العلوم البيئية } \\
& \text { كلية الدراسات العليا والبحوث البيئية - جامعة عين شمس لئس } \\
& \text { غدير مدحت محمد وآخرون }
\end{aligned}
$$

\title{
THE ROLE OF CREATIVITY IN COMBATING ADMINISTRATIVE CORRUPTION FOR ACHIEVING THE DIMENSIONS OF SUSTAINABLE DEVELOPMENT IN GOVERNMENTAL ORGANIZATIONS A FIELD STUDY ON EMPLOYEES IN THE GENERAL OFFICE OF CAIRO GOVERNORATE
}

\author{
Ghadeer M. Mohamed ${ }^{(1)}$; Osama M. Farid ${ }^{(2)}$; \\ Wael F. Abdel Basset ${ }^{(2)}$ and Rasha A. Hussein ${ }^{(3)}$
}

1) General Court of Cairo Governorate 2) Faculty of Commerce, Ain Shams University 3) The Legal Counsel in Cairo Governorate

\begin{abstract}
The study aimed to clarify the relative importance and the inevitable necessity of the role of creativity in combating administrative corruption to achieve sustainable development in government organizations, taking into account the environmental aspects and their effects, with the passage of time the need for creativity increases, as we live in a world in which growth and variables increase, which requires everyone to realize The requirements of development in the present and the future and to achieve the objectives of the study, a questionnaire was designed and collected in the interview, which included a set of phrases that measure the trends of the sample towards the variables of

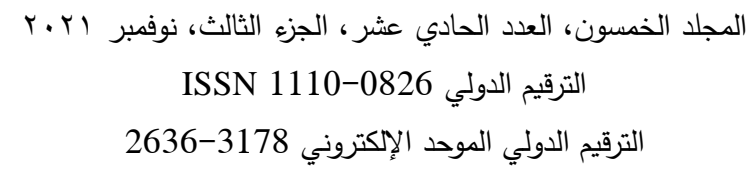




$$
\begin{aligned}
& \text { مجلة العلوم البيئية } \\
& \text { كلية الدراسات العليا والبحوث البيئية - جامعة عين شمس البئ } \\
& \text { غدير مدحت محمد وآخرون }
\end{aligned}
$$

the study. The levels in Cairo Governorate, and the researcher conducted data analysis using the test-re-test method and then according to the reliability coefficient using (Pearson correlation coefficient) the arithmetic averages and standard deviations of the responses of the study sample members related to the reality of interest in the development of creativity in the departments were calculated.

The independent study concluded that the leaders of organizations in the province of Qah There is an average practice by those leaders of some leadership practices that support creativity (represented in goal setting, empowerment, and training), while there was a weak practice of both incentives and rewards, and the results indicated that The process of opening jobs for creative workers requires effective management and a clear institutional strategy. Finally, the study included a number of academic recommendations in addition to recommendations related to managers in the Cairo governorate in general.

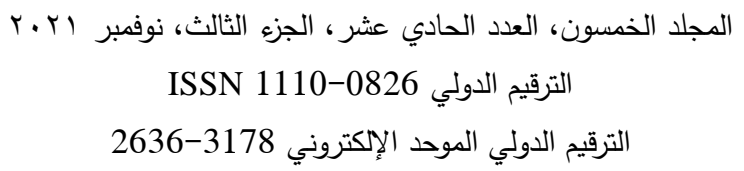

